\title{
A new species of Macaria Curtis (Lepidoptera: Geometridae: Ennominae) from the Andes of northern Chile
}

\author{
Héctor A. Vargas ${ }^{1}$, (D), Axel Hausmann² (D), Luis E. Parra ${ }^{3}$ (D) \\ ${ }^{1}$ Universidad de Tarapacá, Facultad de Ciencias Agronómicas, Departamento de Recursos Ambientales, Arica, Chile \\ ${ }^{2} Z$ Zoologische Staatssammlung München - ZSM, Entomology Department - SNSB, Munich, Germany \\ ${ }^{3}$ Universidad de Concepción, Facultad de Ciencias Naturales y Oceanográficas, Departamento de Zoología, Concepción, Chile
}

\section{A R T I C L E I N F O}

\section{Article history:}

Received 24 February 2020

Accepted 16 June 2020

Available online 20 July 2020

Associate Editor: Lívia Pinheiro

urn:lsid:zoobank.org:pub:88851DE2-92D4-

43B5-BE3F-075166094D42

\section{Keywords:}

Adesmia spinosissima Meyen

DNA barcoding

Fabaceae

Macaria alba (Bartlett-Calvert, 1893)

Macaria mirthae Vargas, Parra \& Hausmann, 2005

\begin{abstract}
A B S T R A C T
Macaria kruegeri Vargas, Hausmann \& Parra sp. nov. is described and illustrated based on adults reared from larvae collected on the shrub Adesmia spinosissima Meyen (Fabaceae) at about $3200 \mathrm{~m}$ elevation in the Andes of northern Chile. Macaria kruegeri resembles Macaria alba (Bartlett-Calvert, 1893), described from southern Chile. However, the two species can be accurately separated based on subtle differences in wing pattern and the shape of the valvula of the male genitalia. In addition, there is a DNA barcode divergence (COI gene) of $4.9 \%$ between both taxa.
\end{abstract}

Macaria Curtis, 1826 (Lepidoptera: Geometridae: Ennominae: Macariini) is a mainly New World moth genus also represented in the Palearctic region (Krüger, 2001; Scoble and Krüger, 2002). Seventy six species were listed from the Neotropics (Pitkin, 2002), with only one species having been added later on (Vargas et al., 2005).

Two species of Macaria have been recorded from Chile (Bartlett-Calvert, 1893a, 1893b; Vargas et al., 2005). Macaria mirthae Vargas, Parra \& Hausmann, 2005 was described from the Atacama Desert, in the northernmost part of the country; its larvae feed on leaves of at least four Fabaceae trees and shrubs, including native species and the invasive Leucaena leucocephala (Vargas \& Mundaca, 2014). Macaria alba (Bartlett-Calvert, 1893a, 1893b) was described from southern Chile, with type locality in Araucanía. It was also recorded in Argentina and Bolivia (Scoble and Krüger, 2002); its host plants remain unknown. Although intrageneric phylogenetic relationships of the species of Macaria have been not explored in detail, the morphology of $M$. mirthae suggests

\footnotetext{
* Corresponding author.

E-mail: lepvargas@gmail.com (H. A. Vargas).
}

relationships with the widespread Neotropical Macaria abydata Guenée, [1858] (Vargas et al., 2005). In contrast, M. alba has a distinctive wing pattern (Scoble and Krüger, 2002) and no closely related species have been mentioned.

In addition to the two species recorded in Chile, adults of Macaria with a wing pattern reminiscent of that of $M$. alba were recently reared from larvae collected on a native shrub in the Andes of the northern part of the country. Morphological examination of their genitalia and analysis of DNA barcode sequences (sensu Hebert et al., 2003) revealed that the specimens of northern Chile represent a new species for which the description is provided below.

\section{Material and Methods}

\section{Sampling, rearing and morphological observations}

The sampling site $\left(18^{\circ} 21^{\prime} 26^{\prime \prime} \mathrm{S} ; 6^{\circ} 37^{\prime} 28^{\prime \prime} \mathrm{W}\right)$ is at about $3200 \mathrm{~m}$ elevation on the western slopes of the Andes of northern Chile, about $4 \mathrm{~km}$ western Zapahuira village, Parinacota Province. It is characterized 
by a tropical xeric bioclimate with seasonal rains between December and March (Luebert and Pliscoff, 2006). Four larvae were collected on Adesmia spinosissima Meyen (Fabaceae) in July 2018. The collected larvae were placed in individual plastic vials with towel paper at bottom and pieces of $A$. spinosissima shoots with leaves as food. The vials were brought to the laboratory, where these were periodically cleaned and fresh pieces of the plant were provided until the larvae finished feeding. The pupae were kept in the vials until adult emergence. Mounting of the adults was performed following standard procedures. The legs of the holotype were removed before mounting and kept in 95\% ethanol at $-20^{\circ} \mathrm{C}$ until DNA extraction. Genitalia dissection follows the procedures described in Vargas (2019). A Sony CyberShot DSC-HX200V digital camera attached to a Leica M125 stereomicroscope and a Micropublisher 3.3 RTV-QImaging digital camera attached to an Olympus BX51 were used to capture the images.

\section{DNA extraction and analysis}

Genomic DNA was extracted from the legs of one adult by staff of the "Laboratorio de Biología Molecular de Plantas" (Facultad de Ciencias Agronómicas, Universidad de Tarapacá, Arica, Chile) following the procedures described in Huanca-Mamani et al. (2015). DNA purification, PCR amplification and sequencing of the barcode fragment with the primers LCO-1490 and HCO-2198 (Folmer et al., 1994) were performed in Macrogen Inc. (Seoul, South Korea) following the PCR program described in Escobar-Suárez et al. (2017). The obtained sequence information was deposited in the Barcode of Life Data Systems (BOLD: Ratnasingham and Hebert, 2007). Its divergence from two sequences of $M$. alba (downloaded from BOLD) was assessed using the Kimura 2-parameter (K2P) approach in the software MEGA6 (Tamura et al., 2013).

\section{Abbreviations of institutional collections}

MNNC Museo Nacional de Historia Natural de Santiago, Santiago, Chile IDEA Colección Entomológica de la Universidad de Tarapacá, Arica, Chile

\section{Results}

Macaria kruegeri Vargas, Hausmann \& Parra sp. nov. urn:Isid:zoobank.org:act:C810E577-19D5-4D62-BE4D-33DD5B87B7DC (Fig. 1)

Type material. HOLOTYPE, male, CHILE: Zapahuira, Parinacota, Chile, emerged August 2018, H.A. Vargas coll, ex-larva Adesmia spinosissima, July 2018, genitalia slide HAV-1340 (MNNC). BOLD specimen page BC ZSM Lep add 00229. Type locality: 18²1'26"S; $69^{\circ} 37^{\prime} 28^{\prime \prime} \mathrm{W}$.

Paratypes. One female, same data as holotype, genitalia slide HAV-1246 (MNNC). Two males, same data as holotype, genitalia slides HAV-1196, HAV-1245 (IDEA).

DNA

One sequence of DNA barcode of 658 bp was obtained from the holotype (BOLD specimen page BC ZSM Lep add 00229). Genetic divergence from $M$. alba (567/633 bp; BOLD specimen pages BC ZSM Lep $07756 / 105148$ ) was found to be $4.9 \% \mathrm{~K} 2 \mathrm{P}$.

\section{Diagnosis}

The wing pattern and male genitalia of $M$. kruegeri resemble those of $M$. alba, described from southern Chile. However, the two species can be accurately separated. The wings are mainly whitish grey in M. kruegeri (Fig. 1A-B), while the wings of $M$. alba are mainly yellowish white (see Macaria alba page at http://www.boldsystems.org/). The apex of the valvula reaches the ventral margin of the sacculus in M. kruegeri (Fig. 1C), while it does not reach the apex of the sacculus in $M$. alba.

\section{Male (Figs. 1A-E)}

Forewing length $14.5-16.1 \mathrm{~mm}(\mathrm{n}=3)$.

Head. Vertex dark brown; frons dark brown centrally with a few creamy white scales scattered, sides yellowish white. Antenna filiform; scape and pedicel mainly light brown with creamy white scales scattered; flagellum dorsally mainly yellowish white, distal half with scattered dark brown scales, ventrally ciliate. Labial palpus with light brown first and second segments and a few scattered yellowish white scales; third segment light brown ventrally, yellowish white dorsally.

Thorax. Whitish grey and greyish brown scales intermixed. Legs mainly concolorous with thorax; tarsus yellowish white; tibial spurs yellowish white. Forewing upperside whitish grey with a few scattered greyish brown scales mainly concentrated close to costal margin; a short greyish brown stripe arising from close to distal fourth of costa; coloration of underside similar but with more abundant greyish brown scales near apex. Hindwing upperside mainly whitish grey with a few scattered dark brown scales; basal two thirds of wing underside with whitish grey and greyish brown scales intermixed, a slightly differentiated whitish grey postmedial line, distal third mainly greyish brown with scattered whitish grey scales.

Abdomen. Whitish grey and greyish brown scales intermixed. Sternum A8 with deeply U-shaped cleft on posterior margin (Fig. 1E).

Male genitalia (Figs. 1C, 1D). Tegumen with deep cleft on middle of anterior margin, a depressed posterior projection at centre. Uncus depressed, sub-triangular with fine setae, two weak horns dorsally near apex, apex slightly concave. Gnathos with conical posterior process at centre. Saccus narrow, U-shaped. Juxta somewhat ellipsoid, ventral margin excavated at centre, dorsal margin slightly expanded dorsad. Valva with costa about two times length and half width of sacculus, medial surface of the free part with fine setae, distal half of the free part slightly taller, apex rounded; sacculus somewhat ellipsoid; valvula as a narrow ridge along the dorsal and distal margins of sacculus, its round apex reaches the ventral margin of the sacculus. Aedeagus cylindrical, length similar to that of costa, a small lateral process near distal fourth.

\section{Female}

Forewing length $14.2 \mathrm{~mm}(\mathrm{n}=1)$.

Similar to male but antennae not ciliate ventrally and sternum A8 not modified like in male.

Female genitalia (Fig. 1F).

Papillae anales lobous, covered with long, fine setae. Apophyses posteriores rod-shaped, about 2.5 times length of papillae anales. Apophyses anteriores similar in shape to apophyses posteriores, length similar to that of papillae anales. Lamella antevaginalis developed as a transversal stripe posteriorly projecting at centre concealing the ostium bursae. Antrum cylindrical, postero-ventral margin posteriorly broadened. Corpus bursae slightly sclerotized, striated. Ductus seminalis arising on the right side of posterior end. Corpus bursae ovoid, membranous, without signa.

\section{Geographic distribution}

Macaria kruegeri is known only from the type locality (Figure 2A), in the surroundings of Zapahuira village, at about $3200 \mathrm{~m}$ elevation in the Andes of the Parinacota Province, northern Chile. 

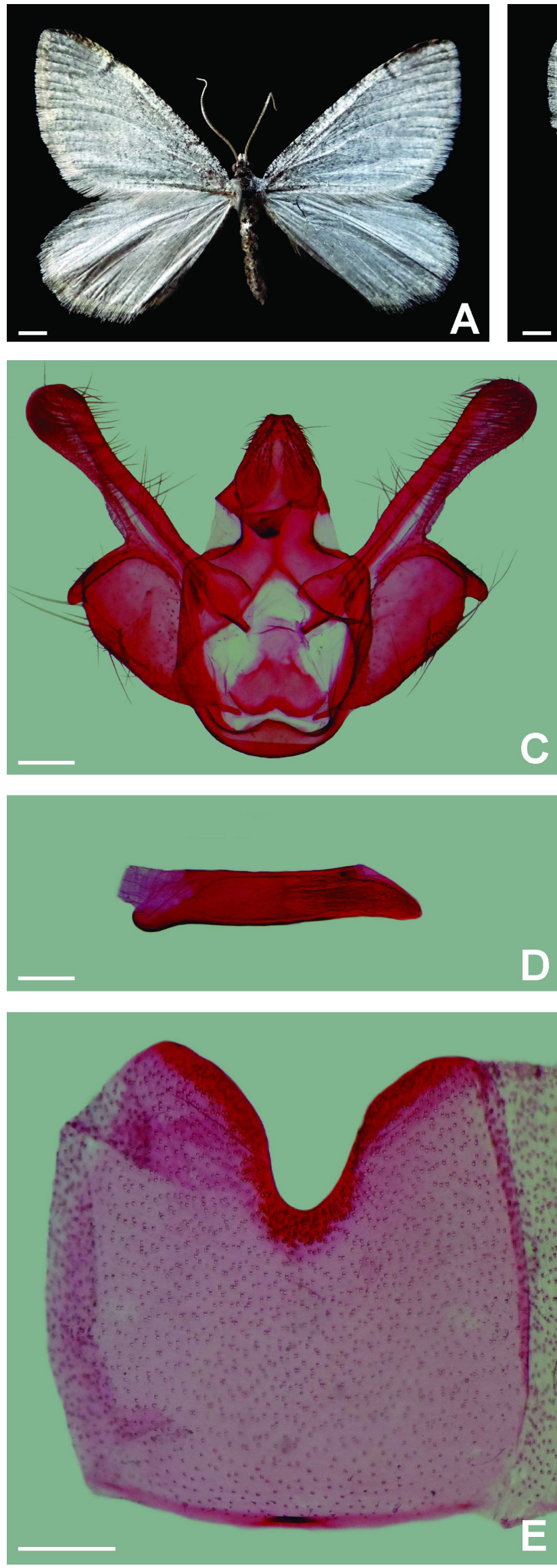
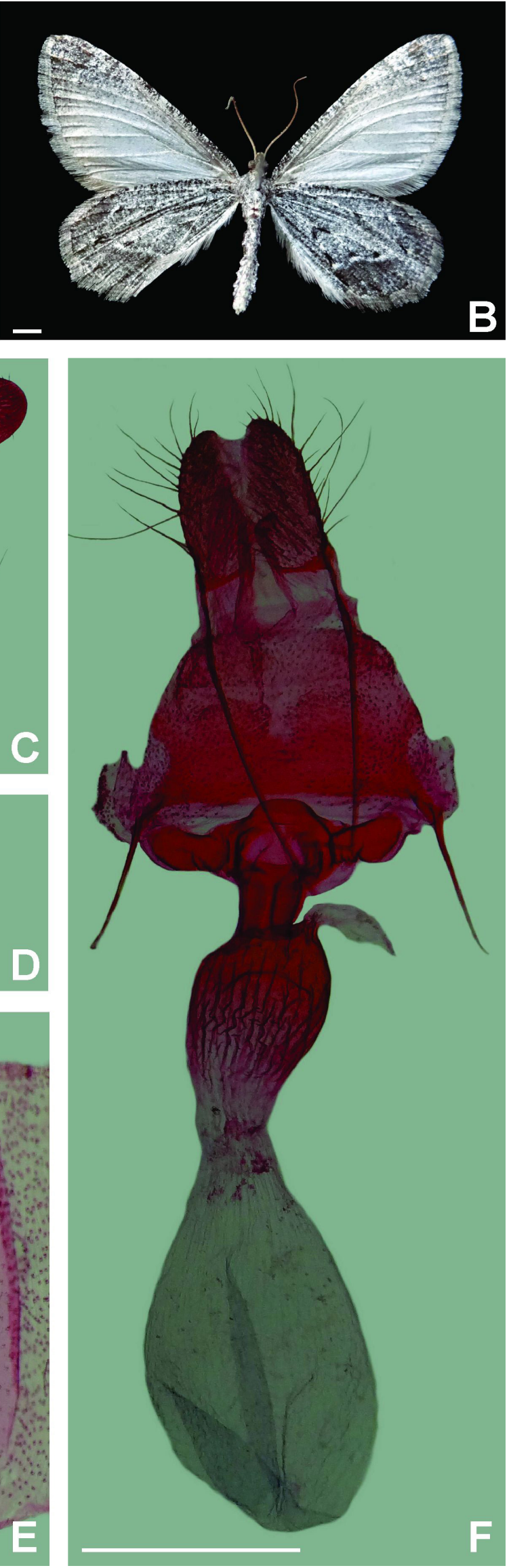

Figure 1. The adult stage of Macaria kruegeri sp. nov. A) Holotype male in dorsal view. B) Holotype male in ventral view. C) Male genitalia in ventral view, aedeagus removed. D) Aedeagus in lateral view. E) Sternum VIII in ventral view. F) Female genitalia in ventral view. Scale bars 2, 2, 0.2, 0.2, $0.2,0.2$ mm, respectively. 

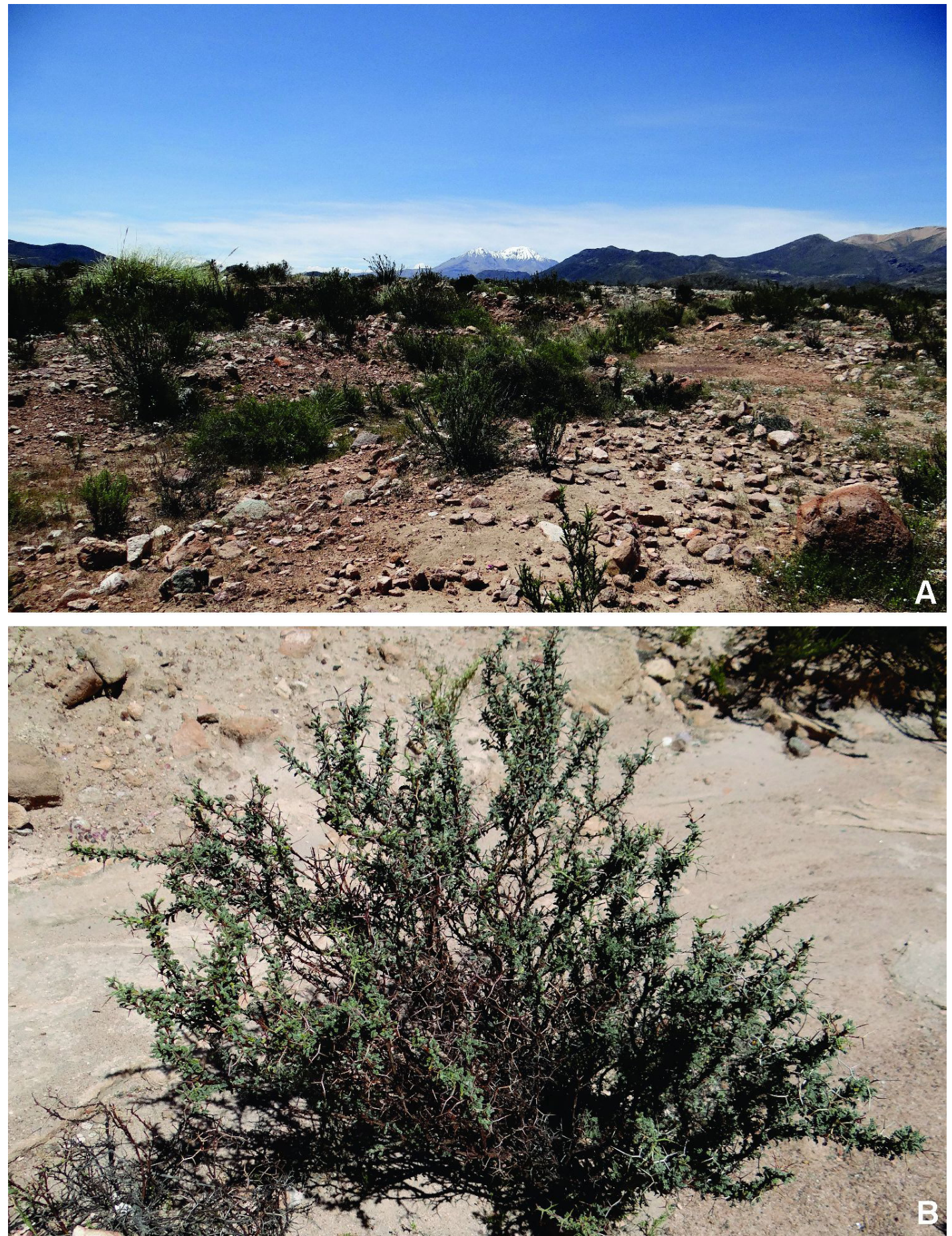

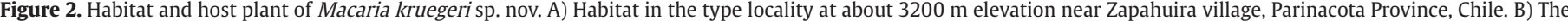
host plant, Adesmia spinosissima Meyen (Fabaceae) in the type locality.

\section{Host plant}

Based on rearing observation and feeding records the larvae of $M$. kruegerifeed on leaves of the native shrub Adesmia spinosissima(Fig. 2B).

\section{Etymology}

The name of the species is dedicated to the memory of Dr. Martin Krüger (Pretoria, South Africa), founding member of the Forum Herbulot research initiative, as an acknowledgement to his outstanding contribution to the systematics of Lepidoptera, especially for his studies on Geometridae.

\section{Discussion}

A wide range of plants are known as hosts of Macaria, including coniferous and dicotyledonous plants (Scoble and Krüger, 2002). The host plants of the Neotropical species of the genus remain poorly known. Besides of the above mentioned host plant records of $M$. mirthae, whose larvae feed on Fabaceae, Osorio (2005) recorded larvae of Macaria 
abydata Guenée, [1858] feeding on two species of Stryphnodendron (Fabaceae), Marconato et al. (2008) described feeding of Erythroxylum microphyllum St.- Hilaire (Erythroxylaceae) by larvae of Macaria regulata (Fabricius, 1775), Geraldo (2011) reported Macaria rigidata Guenée, [1858] feeding on Jacaranda mimosifolia D. Don (Bignoniaceae) and Sousa-Lopes et al. (2016) found Macaria sp. on Mimosa setosa var. paludosa (Benth.) Barneby (Fabaceae). The larvae of $M$. kruegeri have been found only on Adesmia spinosissima, despite they were also searched for on two other congeneric shrubs in the neighborhood of the study site: $A$. atacamensis Phil. and $A$. verrucosa Meyen, suggesting a certain specificity in the host use by this moth. However, further studies are needed to understand better the host plant range of $M$. kruegeri. In addition, although $M$. kruegeri is only known from the type locality, surveys along the geographic range of $A$. spinosissima on the western slopes of the Andes of southern Peru and northern Chile (MacBride, 1943; Gatica-Castro et al., 2015) could be helpful to better characterize the geographic range of the moth.

Macaria kruegeri is the third species of the genus described from Chile and the second one from the arid environments of the northern part of this country. Macaria mirthae, the only other representative of the genus in the north, is easily differentiated from $M$. kruegeri based on wing pattern, shape of male sternum A8, on the presence of a sclerotized sinuous longitudinal stripe with a lobe at the sacculus apex of male genitalia, and on a well-developed signum in the female genitalia (Vargas et al., 2005). In addition, the minimum pairwise divergence between DNA barcode sequences of $M$. kruegeri and M. mirthae was found to be $12.9 \%$ K2P (BOLD accession GBGL17228-15). Accordingly, morphology and DNA barcodes suggest that these two species are distantly related, probably belonging to different lineages within Macaria. In contrast, the remarkably similar morphology and the smaller genetic divergence, suggest a near relationship between M. kruegeri and M. alba. The genetic divergence between M. kruegeri and $M$. alba is well above the DNA barcode divergence recorded for morphologically close species of Geometridae (Hausmann et al., 2009; Skou et al., 2017; Müller, 2018) warranting recognition of the two as different species. However, as only DNA barcodes of three specimens were compared, additional sequences are needed for a better assessment of the genetic divergence between the two species.

The wing pattern of $M$. alba has been described as distinctive among the representatives of the genus (Scoble and Krüger, 2002). In addition, a wide geographic range has been recognized for $M$. alba, including localities from east (Argentina and Bolivia) and west (Chile) sides of the Andes (Scoble and Krüger, 2002). However, the detection of $M$. kruegeriand the extremely subtle morphological differentiation among these two species suggest that records of $M$. alba away the type locality require further confirmation based on morphology and DNA sequence analysis, especially in cases involving localities on the eastern slopes of the Andes. Dey et al. (2019) described four cases of high intraspecific DNA barcode divergence between geometrid moths collected in eastern and western Himalaya, India, and suggested that further in-depth taxonomic studies should be needed. The type localities of M. kruegeri and M. alba are separated by more than $2000 \mathrm{~km}$ and between them there are a considerable diversity of environments characterized by distinctive vegetation (Luebert and Pliscoff, 2006). Certainly, sampling throughout this area would be helpful to assess the taxonomic diversity of Macaria in Chile.

\section{Acknowledgements}

We thank Hossein Rajaei and a anonymous reviewer for kind comments and suggestions, Marcelo Vargas-Ortiz and Wilson Huanca-Mamani for support in DNA extraction, Sebastián Espinoza-Donoso for editing the figures and Lafayette Eaton for editing the English.

\section{Conflicts of Interest}

The authors declare no conflicts of interest.

\section{Compliance with ethical standards}

The specimens were collected in accordance to national legislation of Chile. Type material is deposited in public scientific collections.

\section{Author contribution statement}

All authors conceived the research. HAV conducted fieldwork and dissections of M. kruegeri. LEP conducted dissections of $M$. alba. AH compared morphological structures with congeneric species and provided DNA sequences of $M$. alba. HAV wrote a first draft of the manuscript. All authors approved the final version of the article.

\section{References}

Bartlett-Calvert, W., 1893a. Descriptions of new species of Chilean Lepidoptera. Trans. Entomol. Soc. Lond. 3, 215-222.

Bartlett-Calvert, W., 1893b. Nuevos lepidópteros de Chile. An. Univ. Chil. 84, 813-834.

Dey, P., Hausmann, A., Uniyal, V. P., 2019. Towards creating a DNA barcode reference library of geometrid moths from western Himalaya, India (Lepidoptera, Geometridae). Spixiana 42, 47-59.

Escobar-Suárez, S., Huanca-Mamani, W., Vargas, H. A., 2017. Genetic divergence of a newly documented population of the cecidogenous micromoth Eugnosta azapaensis Vargas \& Moreira (Lepidoptera: Tortricidae) in the Atacama Desert of northern Chile. Rev. Bras. Entomol. 61 (3), 266-270. http://dx.doi.org/10.1016/j.rbe.2017.05.004.

Folmer, O., Black, M., Hoeh, W., Lutz, R., Vrijenhoek, R., 1994. DNA primers for amplification of mitochondrial cytochrome c oxidase subunit I from diverse metazoan invertebrates. Mol. Mar. Biol. Biotechnol. 3, 294-299.

Gatica-Castro, A., Marticorena, A., Rojas, G., Arancio, G., Squeo, F. A., 2015. Estado de conservación de la flora nativa de las regiones de Arica-Parinacota y de Tarapacá, Chile. Gayana Bot. 72 (2), 305-339. http://dx.doi.org/10.4067/S0717-66432015000200013.

Geraldo, M., 2011. Larvas de Geometridae (Lepidoptera) e seus parasitoides em sub-bosque nativo na Universidade Federal de São Carlos, Campus São Carlos, Estado de São Paulo. Dissertação de Mestrado, Universidade Federal de São Carlos.

Hausmann, A., Hebert, P. D. N., Mitchell, A., Rougerie, R., Sommerer, M., Edwards, T., Young, C. J., 2009. Revision of the Australian Oenochroma vinaria Guenée, 1858 species-complex (Lepidoptera: Geometridae, Oenochrominae): DNA barcoding reveals cryptic diversity and assesses status of type specimen without dissection. Zootaxa 2239 (1), 1-21. http://dx.doi.org/10.11646/zootaxa.2239.1.1.

Hebert, P. D. N., Cywinska, A., Ball, S. L., deWaard, J. R., 2003. Biological identification through DNA barcode. Proc. Biol. Sci. 270 (1512), 313-321. http://dx.doi.org/10.1098/rspb.2002.2218.

Huanca-Mamani, W., Rivera-Cabello, D., Maita-Maita, J., 2015. A simple, fast, and inexpensive CTAB-PVP-Silica based method for genomic DNA isolation from single, small insect larvae and pupae. Genet. Mol. Res. 14 (3), 7990-8001. http://dx.doi.org/10.4238/2015.July.17.8.

Krüger, M., 2001. A revision of the tribe Macariini (Lepidoptera: Geometridae: Ennominae) of Africa. Madag. Arabia. Bull. Nat. Hist. Mus. Lond. Ent. 70, 1-502.

Luebert, F., Pliscoff, P., 2006. Sinopsis Bioclimática y Vegetacional de Chile. Editorial Universitaria, Santiago.

MacBride, J.F., 1943. Flora of Peru, Leguminosae. Publ. Field Mus. Nat. Hist. Bot Ser. 33, 3-507. 
Marconato, G., Dias, M. M., Penteado-Dias, A. M., 2008. Larvas de Geometridae (Lepidoptera) e seus parasitóides, associadas a Erythroxylum microphyllum St.- Hilaire (Erythroxylaceae). Rev. Bras. Entomol. 52 (2), 296-299. http://dx.doi.org/10.1590/S008556262008000200010.

Müller, B., 2018. Biston rosenbaueri sp. n. (Lepidoptera, Geometridae, Ennominae) from the Balkan Peninsula. Nota Lepidopterol. 41 (2), 207-213. http://dx.doi.org/10.3897/nl.41.25099.

Osorio, T. C., 2005. Estágios imaturos de Geometridae (Lepidoptera) associados à Stryphnodendron spp. (Mimosaceae) em área de cerrado no município de São Carlos, SP. Dissertação de Mestrado, Universidade Federal de São Carlos.

Pitkin, L. M., 2002. Neotropical ennomine moths: a review of the genera (Lepidoptera: Geometridae). Zool. J. Linn. Soc. 135 (2-3), 121-401. http://dx.doi.org/10.1046/j.1096-3642.2002.00012.x.

Ratnasingham, S., Hebert, P. D. N., 2007. BOLD: the barcode of life data system (www.barcodinglife.org). Mol. Ecol. Notes 7 (3), 355-367. http://dx.doi.org/10.1111/j.1471-8286.2007.01678.x.

Scoble, M. J., Krüger, M., 2002. A review of the genera of Macariini with a revised classification of the tribe (Geometridae: ennominae). Zool. J. Linn. Soc. 134 (3), 257-315. http://dx.doi.org/10.1046/j.10963642.2002.00008.x.
Skou, P., Stüning, D., Sihvonen, P., 2017. Revision of the West-Mediterranean geometrid genus Ekboarmia, with description of a new species from Portugal (Lepidoptera, Geometridae, Ennominae). Nota Lepidopterol. 40 (1), 39-63. http://dx.doi.org/10.3897/nl.40.10440.

Sousa-Lopes, B., Bächtold, A., Del-Claro, K., 2016. Biology, natural history and temporal fluctuation of the geometrid Oospila pallidaria associated with host plant phenology. Stud. Neotrop. Fauna Environ. 51, 135-143. https://doi.org/10.1080/01650521.2016.1199140.

Tamura, K., Stecher, G., Peterson, D., Filipski, A., Kumar, S., 2013. MEGA6: molecular evolutionary genetics analysis version 6.0. Mol. Biol. Evol. 30 (12), 2725-2729. http://dx.doi.org/10.1093/molbev/mst197.

Vargas, H. A., 2019. Female genitalia of Pero obtusaria Prout, 1928 (Lepidoptera: geometridae). Rev. Bras. Entomol. 63 (2), 112-114. http://dx.doi.org/10.1016/j.rbe.2019.01.003.

Vargas, H. A., Mundaca, E. A., 2014. First record of an exotic host plant for the oligophagous moth Macaria mirthae (Geometridae) in the coastal valleys of the northern Chilean Atacama Desert. J. Lepid. Soc. 68 (4), 292-295. http://dx.doi.org/10.18473/lepi.v68i4.a11.

Vargas, H. A., Parra, L. E., Hausmann, A., 2005. Macaria mirthae: una nueva especie de Ennominae (Lepidoptera: Geometridae) de Chile. Neotrop. Entomol. 34 (4), 571-576. http://dx.doi.org/10.1590/S1519$566 \times 2005000400006$. 